International Review of Social History 44 (1999), pp. 159-195

(C) 1999 Internationaal Instituut voor Sociale Geschiedenis

\title{
The Origins of Colonial Labour Policy in Late Eighteenth-Century Madras
}

\author{
Ravi Ahuja
}

\begin{abstract}
Summary: This article challenges the view that the English East India Company was unable effectively to dominate society in the colonial metropolis of Madras before the end of the eighteenth century. Instead it is argued that colonial interventions, even into the social organization of labour, were persistent in goals and methods and acquired institutional forms in the latter half of the century. Hence an early colonial labour policy is clearly discernible. The ruling block's strategies concerning the regulation of labour were not based on laissez-faire ideas but rather on a paternalistic brand of contemporary English social theory. This ideological disposition found practical expression in interventions into the city's labour relations by means of various "police committees". Moreover, British legal techniques were used to regulate labour relations in Madras. On the whole, early colonial labour policy was distinguished from contemporary practices in Britain by a far higher level of coercion.
\end{abstract}

\section{INTRODUCTION}

Imperial historians depicted the British conquest and rule of India as a process in which a stagnating people, without history, was forced into the mainstream of an ever improving and progressing bourgeois world society. In this type of historiography, great British men constituted the historical subject while Indians were identified as its object. Many post-colonial historians have laboured to correct this apologetic depiction, to disclose the dynamics of the subcontinent's pre-colonial social history, to detect the structural determinants of the colonial regime's concrete-historical features that had been created by Indian society itself, and to identify Indian participation in the process of colonial state formation, especially of elite groups and middle classes. This historiographical shift has been most productive

Acknowledgements: This paper is mainly based on sections 6.I-6.4 of Ravi Ahuja, Die Erzeugung kolonialer Staatlichkeit und das Problem der Arbeit: Eine Studie zur Sozialgeschichte der Stadt Madras und ihres Hinterlandes zwischen I750 und I80o, Beiträge zur Südasienforschung, vol. I83 (Stuttgart 1999) where I have presented relevant source material in full detail. An earlier version of the paper was submitted to the fifteenth European Conference on Modern South Asian Studies in Prague, September 8-I2 1998. I owe thanks to Nicole Mayer who helped me to revise it. The remaining errors are, however, my own. 


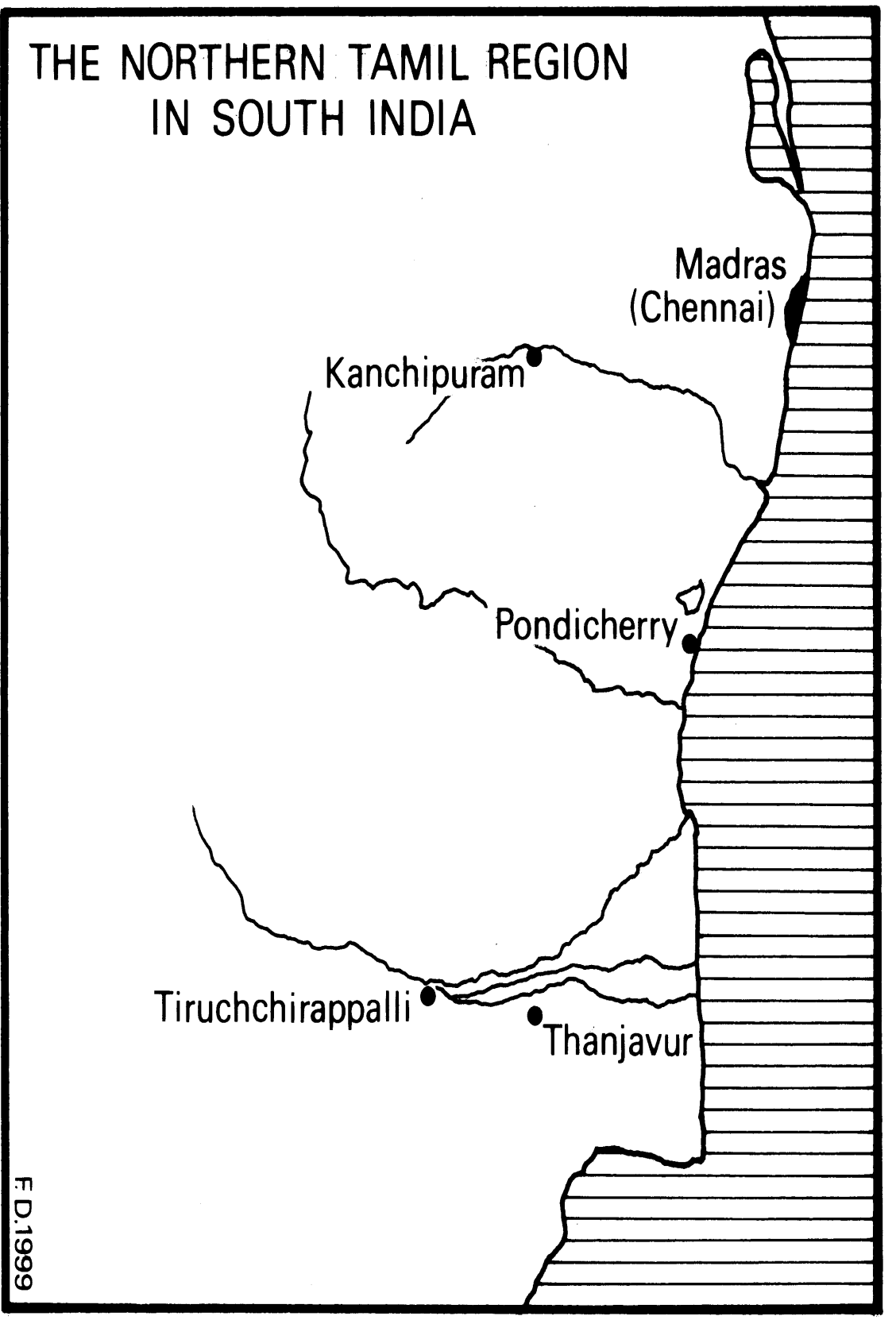

Figure I. The northern Tamil region in south India 
and has promoted theoretical sophistication as well as empirical scrutiny in the writing of South Asia's late pre-colonial and early colonial history. ${ }^{\mathrm{I}}$ However, some - though by no means all - tributaries of this predominantly western post-colonial current of historiography have in turn tended to underrate the impact of colonial intervention in Indian society. Take, for example, Susan Neild-Basu's and Robert E. Frykenberg's well-informed and thoughtful contributions to the eighteenth-century history of Madras City, South India's emerging colonial metropolis. Neild-Basu conceptualizes early Madras as "a city of villages", ${ }^{2}$ where age-old communities preserved their separate identities and had "in their daily activities [...] little if any direct contact with representatives of the East India Company to remind them of English presence". Accordingly, she senses "an atmosphere of general tolerance and noninterference". "Frykenberg takes the argument even a step further as he suggests that early Madras should be regarded as "an assortment of small, hard pieces", "a system of relationships between local communities", "a system of corporate life in which no one community was strong enough, by itself, to dominate or exploit the rest", in which the English "were but one more microscopically tiny speck of local power and influence - one more 'small, hard piece". He contends that the "city-state" was "founded upon a constitution of mutual respect and communal restraint, a system by which common welfare was balanced with ritual distance". "Here", says Frykenberg, "is something, we dare to suggest, so pluralistic and complex that it cannot, by any stretch of mental processes or of simplistic reduction, be casually labelled 'colonial' or 'colonialism'." Though impressed by such an authoritative statement, we are still left somewhat puzzled. Whatever has happened to colonialism, we might ask; when and where did it emerge if not from eighteenth-century East India Company settlements? Or was colonialism merely a self-interested intellectual construction of nineteenth-century middle-class Indians? Our bewilderment deepens as we remind ourselves that the second half of the eighteenth century was a period of almost perpetual warfare between various Indian and

I. For an excellent introduction to the relevant literature up to the late 1980 see the bibliographical essay in C. A. Bayly, Indian Society and the Making of the British Empire, The New Cambridge History of India, vol. 2.I (third ed., Cambridge, 1993), pp. 212-223 [hereafter, Bayly, Indian Society and British Empire].

2. Susan Neild, "Colonial Urbanism: The Development of Madras City in the Eighteenth and Nineteenth Centuries", Modern Asian Studies, I3 (1979), p. 218. For an earlier description of Madras in similar terms see Imperial Gazetteer of India, Provincial Series: Madras, vol. I (1908; New Delhi, 1985), p. 498.

3. Susan Neild-Basu, "Madras in I80o: Perceiving the City", in Howard Spodek and Doris Meth Srinivasan (eds), Urban Form and Meaning in South Asia: The Shaping of Cities from Prehistoric to Precolonial Times, Studies in the History of Art, vol. 31: Centre for Advanced Study in the Visual Arts, Symposium Papers is (Hanover, New Hampshire and London, 1993), pp. 236, 238.

4. Robert E. Frykenberg, "The Socio-Political Morphology of Madras: An Historical Interpretation", Indo-British Review, 2 (1985), pp. 5-6, I0, 15, 22. 


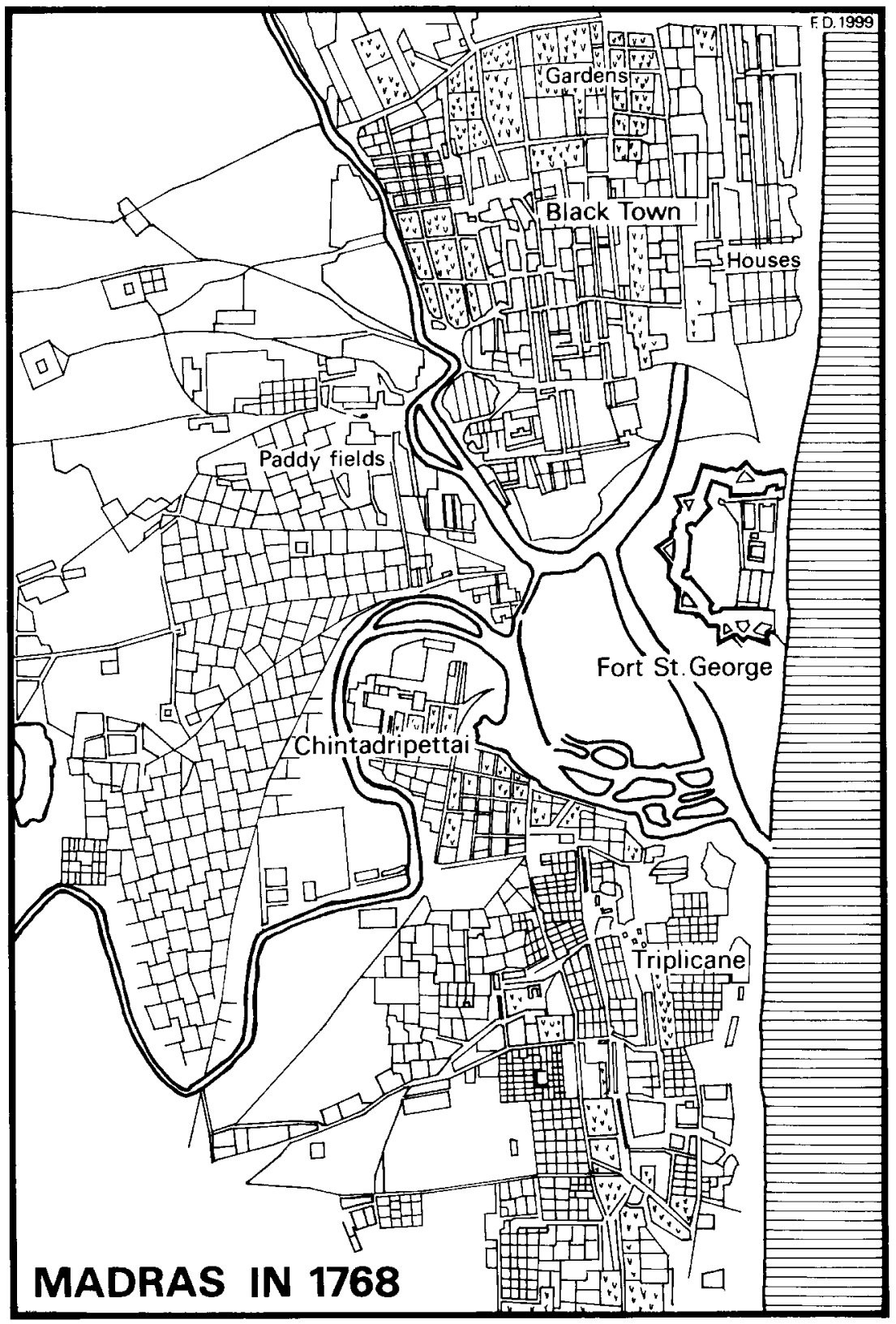

Figure 2. Madras in 1768 , including Fort St George 
European forces, of chronic agrarian crisis, of recurrent famines and epidemics in South India's Tamil region. ${ }^{5}$ Roland Lardinois' cautious calculations indicate a considerable decline in population amounting to about fifteen to twenty per cent in the century's last ten to fifteen years. ${ }^{6}$ How are we then to imagine an "atmosphere of general tolerance and noninterference" in situations of crisis like that of the early 1780 s when the famished poor were forcibly expelled from the city?7 How are we to reconcile a "constitution of mutual respect and communal restraint", say, with the frequent sending out of press gangs to neighbouring villages, the large scale use of corvée and even of slave labour on the fortification works of Fort St George?

This seems to be possible only if the basic social processes of producing and reproducing the conditions of human existence are completely disregarded. Such abstract conceptions of the early colonial period seem to be rooted in two current features of western academic historiography. The first one arises from a partly valid critique of economistic interpretations of history which has unfortunately induced many scholars to ignore economic factors altogether and to confine themselves to an equally reductionist culturalism. The second one consists in what David Washbrook has rightly called the "narrowness and implicit class bias" of many studies of eighteenth-century Indian history. This is not to deny scholars their merits who have focused on indigenous elites, on urban and rural middle classes, or on weavers - the only eighteenth-century plebeian group in the Tamil region that has so far caught the attention of historians to a significant degree. ${ }^{10}$ These studies have been immensely useful. However, we cannot expect our understanding of eighteenth-century societal development and of the early stages of colonial state formation in South India to be adequate if it is based on the exploration of a mere segment of the social relationships conditioning these processes and, accordingly, of no more than a section of the social

5. Cf. Roland Lardinois, "Deserted Villages and Depopulation in Rural Tamil Nadu c. 1780c. I830", in Tim Dyson (ed.), India's Historical Demography, Studies in Famine, Disease and Society, Collected Papers on South Asia, no. 8 (London, 1989), pp. I6-48; [hereafter, Lardinois, "Depopulation in Tamil Nadu"]. See also Ahuja, Erzeugung kolonialer Staatlichkeit, chs 2.I, 4.2, 4.3, 6.7, 6.8, and "Labour Unsettled: Mobility and Conflict in the Madras Region, I750-1800", Indian Economic and Social History Review, 35 (1998), pp. 38I-404.

6. Lardinois, "Depopulation in Tamil Nadu", pp. 32-33.

7. For a full account see Ahuja, Erzeugung kolonialer Staatlichkeit, ch. 6.8 .

8. For an analysis of labour relations see ibid. ch. 5. I also presented an English summary of this chapter ("Labour Relations in an Early Colonial Context: Madras 1750-I800") to the First Conference on Indian Labour History, New Delhi, in March 1998.

9. David Washbrook, "Land and Labour in late Eighteenth-Century South India: The Golden Age of the Pariah?", in Peter Robb (ed.), Dalit Movements and the Meanings of Labour in India (Delhi, 1993) [hereafter, Robb, Dalit Movements and Labour], p. 68.

Io. The most useful starting point for research on other groups of artisans is still A. I. Chicherov, India. Economic Development in the Sixteenth to Eighteenth Centuries. Outline History of Crafts and Trade (Moscow, 197I). 
forces at work. A greater effort in the study of the history of labour could make a considerable difference. Labour history is here not understood as a secluded academic ghetto of somewhat nostalgic backwoods historians but as a discipline that seeks to contribute to the history of society as a whole in permanent co-operation and dialogue with other branches of the histori$\mathrm{cal}$ and social sciences. There may be doubts whether the available sources permit any in-depth study of the history of the Indian "labouring poor" before the nineteenth century. However, the present author's research experiences (which are admittedly confined to Madras records, missionary reports, publications and private manuscripts in European languages dating from between 1750 and I800) indicate that students rather than sources are wanting.

The purpose of this article is not so much to deal with the living conditions and social relations of the Madras "labouring poor" (which I have done elsewhere $)^{\mathrm{II}}$ as to reconstruct and analyse the incipient stage of a colonial labour policy in late eighteenth-century Madras City. Two questions should briefly be dealt with before we start our discussion. First, one might ask whether there was any necessity at all for the Madras representatives of the East India Company to work out a "labour policy" as early as the second half of the eighteenth century? This question seems to be especially relevant as Michael Anderson has only recently denied altogether the existence of anything like a colonial labour policy before the nineteenth century. ${ }^{\mathrm{I2}} \mathrm{We}$ should, however, take account of the fact that requirements of labour resources expanded and changed dramatically as the Company's administration in Madras militarized itself in the course of the last five or six decades of the eighteenth century. Whereas controlling textile production had been the most important aspect of the Company administrators' encounter with Indian labour before, there was now a rapidly growing demand for labour on construction sites and in that often forgotten sector, the services. ${ }^{13}$ From the I750s, large-scale fortification works, involving hundreds of skilled construction workers and many thousands of coolies, were pursued almost continuously - most of what visitors to Madras see today of Fort St George was constructed in these decades. This was also the period when the sepoy, the regular Indian infantryman, entered the historical frame and during which the numerical strength of the regular armed forces under British command shot up from 9,000 in 1763 to 64,000 in 1805 in the Madras region, the southernmost of the three East India Company "presidencies", alone. However, labour demand for unarmed services seems to have out-

II. See Ahuja, Erzengung kolonialer Staatlichkeit, chs 3-5 and the articles mentioned in nn. 4 and 7 above. The following paragraph presents the main argument in a nutshell.

I2. Cf. Michael R. Anderson, "Work Constructed: Ideological Origins of Labour Law in British India to 1918", in Robb, Dalit Movements and Labour, pp. 90-9I.

13. Cf. Dharma Kumar, "The Forgotten Sector: Services in Madras Presidency in the First Half of the Nineteenth Century", Indian Economic and Social History Review, 24 (1987), pp. 367-393. 
numbered that for armed services by far; facilities for overland transport and shipment of goods and persons proved to be even more crucial than military recruitment or training during the Company's frequent wars with the French and with the powerful sultanate of Mysore. Demand for household and other menial services in Madras expanded too, in proportion to the swiftly increasing number of British administrators, army officers and soldiers. The main conditions under which the Governor-in-Council of Fort St George, the colonial government of the Madras Presidency, had to materialize these ever growing labour requirements were very roughly: (i) a general scarcity of labour; (ii) a correspondingly high level of horizontal and vertical labour mobility; and (iii) wages (and other forms of remunerating labour) that did not merely double nominally in the course of the period under review, but also rose in real terms (though positive figures cannot be ascertained for the development of real wages as yet). These conditions were supplemented and partly counterpoised by the effects of agrarian crisis, intensive warfare, famine and epidemic, namely (iv) the periodical occurrence of severe shifts in the demand for labour which contributed to (v) the uneasy coexistence of various types of labour relations ranging from chattel slavery through various other "indigenous" and "exogenous" forms of unfree labour to relations approximating free wage labour. These conditions and the imperatives of war forced the Governor-in-Council to take a more active stand in respect of labour issues and precluded total reliance on corporate social structures (such as caste) and private subcontractors for recruiting and controlling labour. As militarization required more and more direct links between the early colonial regime and the lower strata of regional society, some sort of labour policy became indispensable and, contrary to Michael Anderson's assumptions, did actually come into existence.

Secondly, the question might be raised whether it is really possible to talk about a labour policy at such an early stage of colonial rule, as this term would suggest some degree of consistency in goals, means and procedures? It is true that the Company's military despotic state was only just about to unfold, while competing or hierarchically subordinated power centres coexisted, limiting the early colonial state's scope of influence and defeating many of its administrative initiatives. It is also true that the colonial regime's highly sophisticated bureaucratic apparatus then existed only in rudiments, and that the Governor-in-Council's legislative, jurisdictional and even administrative competencies remained fairly limited before the Company's Charter of 1793. Moreover, record-keeping in Fort St George was far less differentiated and comprehensive than in later decades, thus impeding the development of a continuous political and administrative style. As far as labour issues are concerned, the present article will, however, try to show that repeated attempts were made on the part of the colonial oligarchy and administration to solve identical problems by means of implementing very similar strategies and measures. In this sense it is possible to identify a 
consistent colonial labour policy in late eighteenth-century Madras: the ruling block of British administrators, military commanders, merchants and professionals collectively perceived the world of labour as an area of policy that required regulation. They had fairly precise ideas about the proper place of the "labouring poor" in the society of Madras and its hinterland and about how it should be guaranteed that they stayed in that place.

The present article will try to prove, first of all, that even the Madras ruling block's ideas and strategies concerning the regulation of labour were not based on the concept of a free market in labour. When dealing with labour issues the British elite did not put too much trust in the powers of the invisible hand. Secondly, an overview of practical early colonial interventions into the city's world of labour by means of so-called "police committees" will be presented. Thirdly, early attempts to regulate labour relations through jurisdiction based on ancient and contemporary English labour legislation will be traced. In conclusion, we shall turn to the question of whether there was anything specifically colonial about the labour policy pursued by the Governor-in-Council of Fort St George in the later years of the eighteenth century.

\section{"FRAUD AND INDOLENCE OF LABOURERS AND SERVANTS”: THE LEGITIMATION OF WAGE FIXING AND OF THE OBLIGATION TO WORK}

What the "gentlemen of the settlement" considered the appropriate place in society of the Madras "labouring poor" can only be retrieved from the sources with difficulty as there is hardly any comprehensive discussion of the problem in contemporary sources. However, numerous passing remarks of Company servants, European merchants, and professionals can be gleaned from records and private manuscripts. They indicate an ideological disposition concerning this subject shared by most influential representatives of the city's early colonial oligarchy. There was a distinct conception of the indigenous labouring woman and man, of their mental disposition and of the compulsions directing their behaviour. This conception was applied to a wide range of jatis (occupational caste groups), differing considerably in social status, religious practice, occupation and income.

"It is well known, that the Men who ply the Boats are of a Cast the most Ignorant and consequently the most froward of any on the Coast, Extremely addicted to Drunkenness and ever unwilling to work whilst they have any Thing to spend." ${ }^{\text {" }}$ Such was the opinion of Robert Clive, Robert Orme and other members of the Council of Fort St George in their 1756 report

I4. Oriental and India Office Collections, British Library, London [hereafter OIOC], Madras Public Proceedings [hereafter MPP] (P/240/I4), September 6, 1756, p. 496. 
on the state of the harbour services and on the so-called "boat people" who were required for the shipment of goods and persons. In 1775, their notorious "nature", their drinking habits, and apprehensions that high wages could induce them to idleness became a matter of the council's deliberations again. I5 Just before the turn of the century it was George Taswell, "Master Attendant" (port captain) and Justice of the Peace in Madras, who brought up the issue and pointed out the "habitual indolence" of the stevedores who invariably fell into the sins of "dissipation" and "idleness" when paid in excess of their families' subsistence requirements. ${ }^{16}$ Other occupational groups received similar assessments. In I774, the tank diggers were characterized as "idle" and "unruly" by the Committee of Works. ${ }^{77}$ About a decade later British notabilities boiled with indignation about their domestic servants' "indolence", about the "impositions" "every family" suffered daily, about the "shameful impositions" of servants, craftsmen, labourers, and coolies, about the "fraud and indolence of Menial Dealers, Labourers and Servants". ${ }^{18}$ Chief Engineer Major Maule proposed determined action against the inhabitants of the city's largest settlement of paraiyars $^{19}$ in 1792 in order to "repress that opposition $\&$ misconduct which it is highly probable these Drunken \& riotous People may be guilty of [...]" as "Extreme intemperance $\&$ addiction to Riot" constantly prevailed among them. ${ }^{20}$ Two years later the local weekly Madras Courier condemned the "arbitrary charges" and "wayward conduct" of palanquin bearers who were meaningfully labelled as "sturdy coolies". ${ }^{21}$ Sinnappah Arasaratnam writes that weavers too were frequently characterized as "lazy", "profligate", "drunken", "deceitful", "tumultuous" or "dissolute", as indulging in wasteful festivities and addicted to prostitution. He points out convincingly that some of these condemnations referred to the customary dedication of weavers' daughters to

15. Ibid., (P/240/39), March 24 I775, pp. 335-336.

I6. Ibid., (P/24I/72), May 26 I797, p. 1779 and ibid., (P/242/I), December 22 1797, pp. 40284029 .

17. Ibid., (P/240/37), January 2I I774, p. 55.

I8. Ibid., (P/240/63), May I2 I786, pp. 655, 664 .

19. Members of the largest community of "untouchables" in this region who were mainly employed as agricultural labourers but also constituted a large section of the urban labour force. 20. OIOC, Mackenzie Collection General, vol. 69 ("Extracts Chief Engineer's Books Fort St. George Relating to some Principal Points of the Survey \& the Engineer's Department [...]"), Major Maule to Governor Sir Charles Oakeley, undated, probably April 1792.

2I. Madras Courier, no. 463, August 22 1794. The adjective "sturdy" had a distinctly criminalizing connotation in this period. In England those who were "unwilling" to work though in good bodily health were classified as "sturdy beggars" and could be confined in bedlams or work houses. Cf. Joanna Innes, "Prisons for the Poor: English Bridewells, I555-1800", in Francis Snyder and Douglas Hay (eds), Labour, Law, and Crime. An Historical Perspective (London and New York, 1987), pp. 49-50; [hereafter, Innes, "English Bridewells I555-1800"]. See also The Compact Oxford English Dictionary, photomechanically reproduced ed. of Oxford English Dictionary (second ed., London, I989; 1994), pp. 1938-1939. 
temples as devadasis ${ }^{22}$ and to non-brahmanical ritual practices observed by the weavers which involved the consumption of alcohol and ecstatic dances. Accordingly, we should also assume for other occupational groups that the British notabilities' reflections on the "labouring poor's" "mentality" were, though of course highly coloured by prevailing clichés, at least partly based on actual observations. Various modes of behaviour of labouring people in Madras could be construed as "indolence" or "sin": such as the insistence of various occupational groups on pursuing sideline occupations along with their Company assignments, such as the "lack of work-discipline" of people accustomed to irregular work rhythms and not yet to the clock's regime, such as the practice of agrarian labourers seeking employment in town only during the lean seasons, such as the habitual reclamation of product shares by labourers that could be interpreted by their employers as embezzlement, such as frequent incidents of insubordination when artisans and coolies tried to improve their working conditions or wages. ${ }^{23}$ Alcohol was mainly consumed by members of subordinated castes - the type of liquor produced from palm sugar in considerable quantities in a Madras godown was in fact called Parriar [= pariah] Arrack. ${ }^{24}$ British reflections on the Madras poor were thus no doubt related to observations of social phenomena. These observations were, however, remoulded in the process of reflection by those patterns of thought eighteenth-century gentlemen returned to when imagining the poor. We need to know more about these ideological elements as they implied political preferences.

Christopher Hill and others have shown how lamentations over the poor's "moral depravity" came to be a basic ingredient of gentlemanly discourse as English society became more differentiated and new forms of labour organization emerged in the early modern period. ${ }^{25}$ The English "labouring poor" were characterized in similar terms as the working people of Madras. Idleness, it was said, was entrenched in their nature and they "would work no more than they had to. The moment they had spare cash they would squander it, turning to drink, debauchery, and crime" ${ }^{26}$ Hence

22. The term devadasi (literally: "female servant of god") denotes temple servant as well as temple prostitute.

23. Some of these aspects are discussed in Ahuja, Erzeugung kolonialer Staatlichkeit, chs 3-5.

24. Records of Fort St George, Madras, Diary and Consultation Book, 30 May 1758, p. 98; [Benjamin Schultze], "The large and reknowned town of the English Nation in the East-Indies upon the coast of Coromandel, Madras or Fort St George [...]", (Halle, Saxony, I750), p. 4 and OIOC, MPP (P/240/26), April II, I768, p. 3I2.

25. Christopher Hill, Change and Continuity in Seventeenth-Century England (rev. ed., New Haven and London, I991), p. I00; see also Thompson, Customs in Common, pp. 38-42.

26. Roy Porter, English Society in the Eighteenth Century in J. H. Plumb (ed.), The Pelican Social History of Britain (Harmondsworth 1982; 1986), p. I45. See also: ibid. pp. I05-I06, I46; John Rule, The Experience of Labour in Eighteenth-Century Industry (London, 198I), pp. 52-57; Innes, "English Bridewells I555-I800", p. 42 and Thompson, Customs in Common, p. 37. For a contemporary statement of the matter see also Frederic Morton Eden, The State of the Poor (London I797; 1966), vol. I (p. 387 and passim) and 3, p. ccclxxxii. 
a notion of a distinct class immorality of the poor had already been generated in England and was now applied to an Indian context.

Meanwhile, another ideological device had been forged by European notabilities in India which proved to be as effectual. Robert Orme, the East India Company's official historian and former councillor of Fort St George, summarized and publicized this argument as follows:

The mechanick or artificer will work only to the measure of his necessities. He dreads to be distinguished. If he becomes too noted for having acquired a little more money than others of his craft, that will be taken from him. If conspicuous for the excellence of his skill, he is seized upon by some person in authority, and obliged to work for him night and day, on much harder terms than his usual labour acquired when at liberty.

Hence all emulation is destroyed; and all the luxury of an Asiatick empire has not been able to counteract by its propensity to magnificence and splendour, the dispiriting effects of that fear which reigns throughout, and without which a despotick power would reign no more.

While "Asiatic despotism" killed entrepreneurial initiative, the hot climate generated a weakly physiognomy, argued Orme, and concluded that the subcontinent's inhabitants could be called "a lazy people". ${ }^{27}$ Similar sentiments were uttered in other contemporary publications in Europe $e^{28}$ as well as in Madras sources. Innes Munro, for instance, condemned the "excessive laziness of the natives" who were sitting all day in front of their houses in a "state of inactive stupidity". ${ }^{29}$ Lionel Place, Collector of the Jagir (the district around Madras city), reported that "the exercise of authority" was required "to break the Inhabitants of those habits, which so strongly pervaded them, $[\ldots]$ and to stimulate them to Industry" ${ }^{30}$ One of the Madras Courier's correspondents sneered at "Asiatic Insolence" while another rejoiced that "providence" (the Company apparently considered to be its agent) had roused the natives "from apathy, and called them unto being".

Less popular seem to have been theories that identified the caste system as the main cause of the poor's moral flaws. The reason for this is possibly that Company administrators found jati structures frequently indispensable for recruiting and controlling labour and thus found little reason to con-

27. Robert Orme, Of the Govt. and People of Indostan. Extracts from the Author's Work Entitled Historical Fragments of the Mogul Empire [First ed. London, I805], N. Hassan et al. (eds), pp. 6-9. 28. See e. g. August Hennings, Gegenwärtiger Zustand der Besitzungen der Europäer in Ostindien, vol. 2 (Hamburg and Kiel, 1785), pp. 478-479.

29. Innes Munro, A Narrative of the Military Operations on the Coromandel Coast Against the Combined Forces of the French, Dutch, and Hyder Ally Cawn from the Year 1780 to the Peace in 1784 in a Series of Letters (London, I789), p. 67.

30. Lionel Place, Report on the Jagir (I799), in OIOC, Board's Collection (F/4/III), $\$ 685$, p. 4II. 31. Madras Courier, no. 496, April 8, 1794 and no. 490, February 25, I795. See also ibid., no. 475, November 14, 1794. 
demn them wholesale. ${ }^{32}$ However, the German August Hennings, mainly drawing on Protestant missionary reports from Madras, wrote as early as in the 1780 os that the caste system impeded "all excellence in true merits, or perfection in civic and moral virtue and in related usefull skills and talents". Especially the paraiyars were, on account of their depressed situation, "thievish, mendacious, slavish, only to be governed and restrained to discipline by means of blows". ${ }^{33}$

Another theory was entered into the Company's records in 1778 when Richard Wilson, Anglican missionary in Tiruchirapalli, tried to gain the Governor-in-Council's support for an orphanage for male children of European soldiers and Indian, usually low caste, women. The "Offspring of an European only one degree degenerated", wrote Wilson indignantly, usually spent their childhood and youth "amongst the very Dregs of the People, from whom so deep a Tincture of Wickedness \& Meanness is imbibed \& so strong an Inclination to Idleness grafted on the Mind, that the best Advice \& Instruction in future proves of no avail". The "Roads to Wickedness \& pernicious Indolence" were many and various and only few led to "Purity of Manners and Industrious virtue". The patriotic divine could only make out a single path through British religious and secular institutions that could lead the soldiers' children to decency. It was to begin in the Protestant orphanage and to end in the army barracks. But even this path could only reach its destination if "as total a Separation as possible from Indians, \& Indian Manners[,] from popish Priest Craft and heathenish Superstition" was achieved. Gentlemanly notions of class morals were here blended with religious and early racist sentiments. ${ }^{34}$

Whether European notabilities considered the Madras poor's "wickedness" and "indolence" as being based on distinct class morals or on "Asiatic despotism", whether they employed auxiliary arguments of caste, religion, climate, or "race" was, however, only of limited practical relevance. The same conclusion could be drawn in each case: in South India, the labour market could not regulate itself. The "labouring poor" needed restraint, authority, even compulsion to be roused from apathy. The most lucid formulation of this widespread idea can be found in Collector Lionel Place's 1799 report which will, therefore, be quoted at length:

The Wages of labour are said always when left to their natural Operation to be proportionate to the price of provisions, and to rise or fall with them. They cannot be less than subsistence requires, and if much more they invariably occasion Idleness; for a relaxation from Work is almost the only enjoyment that the labouring

32. Cf. Ahuja, Erzeugung kolonialer Staatlichkeit, p. 249, n. 40.

33. Hennings, Besitzungen der Europäer in Ostindien, pp. 485, 487-488.

34. OIOC, MPP (P/240/46), June I2 1778, pp. 703-716. Elements of an early racism can also be found in Innes Munro, Military Operations on the Coromandel Coast, pp. 49-5I (written in about 1780). 
poor languish for, and if a man in three or five days can earn sufficient to subsist him for a week, he will be idle the rest of it. It is always an object to give this class of People a natural, or compulsive incitement to employ themselves.

[...] An intimate knowledge of the Habits \& Sentiments of the Natives in general, shews that they do not always yield to the Impulse of Interest; and it is a common observation among themselves, that to be roused to Industry \& Exertion, the obligation of duty must be heavy. They are remarked for Apathy, a disposition which, considering the antient Prosperity of the Country, may very likely have been produced by the weight of oppression exercised by a foreign Government over them, and is, I think, to be corrected by a System better adapted to their Genius and Principles. But if this Disposition appears less in the Weavers [...]; there is a profligacy of Character among them in this Country which is equally inimical to real Industry [and] requires to be restrained. ${ }^{35}$

Though "low-wage theories" were hegemonic in seventeenth- and eighteenth-century England too, ${ }^{36}$ it is useful to remind ourselves that alternative views had become quite influential by the time Place penned his reports. ${ }^{37}$ Adam Smith's Wealth of Nations, which dealt at length with wages and wage regulation, had been already published in 1776 . A comparison of the Collector's ideas on wages with those of the founder of classical political economy helps to clarify the specific ideological foundations of early colonial labour policy:

(I) Place assumed a direct, mechanical dependence of wages on food prices. In Smith's view only the level of minimum wages was determined by the wage labourer's subsistence requirements. Beyond that wages rose in a prospering economy while they fell to a level setting subsistence at risk in a decaying economy - for the latter case he referred to Bengal as an example. ${ }^{38}$

(2) In Place's view, high wages only induced idleness among the poor. Smith had dismissed this old argument: "The wages of labour are the encouragement of industry, which, like every other human quality, improves in proportion to the encouragement it receives." ${ }^{39}$

(3) Place also reiterated the seasoned hypothesis that a wage earner would only work as many days as he needed. Smith had only conceded that a minority might respond in this way. The majority would, however, tend to overwork themselves when piece rates were high. Moreover, excessive

35. Place, Report on the Jagir (I799), $\ 356-7$, pp. 228-229.

36. Maurice Dobb, Wert- und Verteilungstheorien seit Adam Smith. Eine nationalökonomische Dogmengeschichte (Frankfurt a. M, I977), p. 6I, n. 34 .

37. Here John Rule's observation is relevant that both wage theories reflected different aspects of the contemporary world of labour - in Smith's case a less predominant one. Rule, The Experience of Labour in Eighteenth-Century Industry, p. 57.

38. R. H. Campbell and A. S. Skinner (eds), The Glasgow Edition of the Works and Correspondence of Adam Smith (Oxford, I979), vol. 2.I, pp. 85-9I, II3-II4, 266.

39. Ibid., p. 99. 
exertion during one part of the week was the reason for idleness during the other - the labourer was simply following "nature's call" which to ignore would only affect his health. ${ }^{\circ}$

(4) Smith considered a human being's property in his own "labour" as "the most sacred and unviolable" one as it constituted the "original foundation" of all other property. Hence no person was to be impeded in employing "this strength and dexterity in what manner he thinks proper without injury to his neighbour" ${ }^{41}$ In direct opposition, Place advocated direct political intervention into this "property right": the lower classes had always to be given a "natural" (i.e. economic), or "compulsive incitement". It was exactly at this point that Place transgressed the bounds of general wage theory and turned to the peculiarities of Indian "Habits \& Sentiments" (or, what would today be called "culture") in order to confer additional legitimacy to compulsory measures: as Indians did not always act according to their (economic) interest considerable pressure was required to rouse them from "apathy". Stating a distinct theory of wages for India helped to fend off liberal criticism of the Company's interventionist policy as the new political economy's relevance for India could thus be denied.

(5) Place's and Smith's conclusions concerning the advisability of wage regulations could obviously not coincide. Adam Smith held that law could never regulate wages properly. He even considered such regulations as harmful as they discouraged more diligent workers by assigning to them the same pay as to ordinary labourers. ${ }^{42}$ Place did not only advocate wage regulations in theory. In an earlier report he had defended a "determinate scale", a "Chattum of Wages" ${ }^{43}$ which he had himself introduced for construction workers in Kanchipuram with the support of nattavars (local magnates). For Madras City he had advised "a revision of the rates of Wages in general, [to] be made under the direction of the Judicial authority". ${ }^{44}$

We shall see below that Place's reasoning on wage regulations reflected a broad consensus among the gentlemen of the settlement. Beforehand, however, some implications of the material presented so far should be underlined. Clearly, the Madras notabilities' notions of labour, labourers and labour relations were not those of laissez-faire political economy. Wage earners were far from being accepted as an equal party to a contract with

40. Ibid., pp. 99-Ioo. See also Eden, The State of the Poor, vol. I, pp. 438-447.

4I. Campbell and Skinner, Works and Correspondence of Adam Smith, vol. 2.I, p. I38.

42. Ibid., pp. 95, I57-I58.

43. Possibly a corruption of Hindustani chitti (letter, certificate); cf. Henry Yule and A. C. Burnell, Hobson-Jobson (Delhi 1903; 1984), p. 203.

44. Lionel Place, Report on the Jagir, October 6 1795, in OIOC, Board's Collection (F/4/3I), $\$ 5 \mathrm{I}-54$. 
unrestricted property in their labour power. Instead ideas generated in the sixteenth and seventeenth centuries still prevailed according to which the poor were not free but "servants" who were obliged, bound to work. This duty was to be enforced, if necessary, by compulsion. ${ }^{45}$ British notabilities had to punish labourers in case of "fraud" and "indolence" not only because this behaviour was sinful but because God had, according to a contemporary Anglican bishop, "formally put the poor under the supervision of the rich" ${ }^{46}$ "Idleness" was also a worldly crime, a transgression of law according to the legal ideas British gentlemen brought with them to Madras. From 1744 onwards various vagrancy acts had been introduced in England which provided for the confinement in gaol for one month of "idle and disorderly people". This category explicitly included "Persons, who, not having wherewithal to maintain themselves, live idly, without employment, and refuse to work for the usual wages". ${ }^{47}$ This formulation indicates that notabilities promoted wage-fixing not merely because it saved them expenses but also because it was an important instrument in the regulation of labour relations. "It is the same thing to have the liberty of working or not at your own pleasure, and to have the absolute nomination of the price at which you will work", wrote Henry Fielding in defence of wage fixing by JPs in $1753 .^{48}$ The "labouring poor's" obligation to work could only be implemented if wage rates they could be forced to accept had been fixed beforehand.

\section{INSTITUTIONALIZING THE REGULATION OF LABOUR RELATIONS: THE CASE OF THE MADRAS POLICE COMMITTEES}

In the early decades after the foundation of Fort St George in 1639, Indian merchants possessed great influence with the Governor-in-Council which

45. E. P. Thompson argued that while unfree labour relations disappeared from England in the course of the eighteenth century the related ideas concerning "service" proved to be more enduring among the "masters": "They clung to the image of the labourer as an unfree man, a 'servant': a servant in husbandry, in the workshop, in the house. (They clung simultaneously to the image of the free or masterless man as a vagabond, to be disciplined, whipped and compelled to work.)” Thompson, Customs in Common, p. 36.

46. Bishop Butler, quoted in Porter, English Society in the Eighteenth Century, p. 310. On religious motivations of contemporary English policy concerning the poor see also: ibid., pp. 308-3I6; Innes, "English Bridewells I555-I800", pp. 49-52, 60, 84, IOI, and Nicholas Rogers, "Policing the Poor in Eighteenth Century London: The Vagrancy Laws and Their Administration”, Histoire social/Social History, 24/47 (I99I), p. I28. For a graphic illustration of contemporary gentlemen's inclination to preach morals to the plebeian classes see William Hogarth's series of engravings "Industry and Idleness".

47. Eden, The State of the Poor, vol. I, p. 307. See also: ibid., pp. 308-310; ibid., vol. 3, p. cclvi and Nicholas Rogers, "Vagrancy, Impressment and the Regulation of Labour in EighteenthCentury Britain", Slavery and Abolition, I5 (1994), pp. I04-IOS [hereafter, Rogers, "Regulation of Labour in Britain"].

48. Quoted from Eden, The State of the Poor, vol. I, p. 322. 
rested partly on their ability to recruit and control the necessary labour force by way of a client relationship or other, as yet unknown methods. ${ }^{49}$ However, from about the middle of the eighteenth century the growing administrative and military apparatus in Madras intervened more frequently and directly in the regulation of labour relations in sectors of immediate relevance to the Company. Thus the successive Governors-in-Council involved themselves in fixing the wages for sepoys, construction workers, stevedores, or cloth-bleachers. Voluntary or compulsive recruitment of labourers or reclaiming corvée from villages was taken care of by the Company's paid agents or by European as well as Indian contractors. There was also a tendency in the policies of most Governors-in-Council to solve problems by establishing more lasting institutional arrangements, i.e. by means of generating state-like structures. Various departments of the Company's administration in Madras dealt with labour issues such as the Chief Engineer and the Committee of Works, the Master Attendant and the Board of Trade, the Export Warehousekeeper and the Rental General and Scavenger or, of course, the military paymasters. ${ }^{50}$ By the last quarter of the century aspects of the urban world of labour came into the range of administrative initiatives which were not so vital for the Company's commercial and military interests but by no means unimportant to the city's European (and partly even Indian) notabilities. They concerned various types of artisans, but mainly coolies, palanquin bearers and domestic servants. In this section we shall focus on these initiatives.

As early as I764 European notabilities asked the JPs (i.e. the Governor-inCouncil in their capacity as judges) to introduce various municipal regulations. One of the grievances they complained of was "that the Wages of Servants and Rates of Labour have lately encreased to a very High pitch and are Still Encreasing for the Remedying of which Some Establishment seems Absolutely Necessary". ${ }^{\text {II }}$ Practical measures in institution-building were, however, only taken in 1770 when the Governor-in-Council decided to meet at least twice a month as a "Board of Police" and to engage the Reverend Benjamin Salmon as the Board's secretary for £ioo per annum..$^{52}$ The term "police", it should be noted, did not obtain its modern meaning

49. For example, in a 1786 petition of the idangai (i.e. left hand) caste division (dominated by Chettiar merchants), it was still claimed that the petitioners' ancestors had been "by Encouragement and good treatment aforesaid Employed to provide, which they performed not only with fidelity and truth, but also with an Immense trouble and pains, especially, in the Collecting and procuring of workmen [...] from different quarters". OIOC, MPP (P/240/64), August 5 1786, pp. I358-I359.

50. Most aspects touched upon in this paragraph are discussed in detail in chs $3-5$ of Ahuja, Erzeugung kolonialer Staatlichkeit. Problems of military labour would, however, merit another study.

5I. Tamil Nadu State Archives, Chennai [hereafter, TNSA], Quarter Sessions, vol. I, July II I764,

pp. I6I-I62. See also ibid., July I8 I765, p. I83.

52. OIOC, MPP (P/240/29), March 2 I770, pp. 173-177. 
before the end of the eighteenth century. In the Governor-in-Council's view the word implied no more than "the Government of a Town or City as far as respects the Inhabitants". 53 They argued that the Company's recent "Access of Power" had considerably increased the population of Madras which made further institutional steps necessary to decide legal disputes between Indians, to safeguard "Order \& good Government" and to regulate prices of provisions and wages. ${ }^{54}$ The extension of jurisdictional powers to disputes between Indians clearly conflicted with the East India Company's Charter of 1753.55 It was probably for this reason that the Board of Police was discontinued only one year after its establishment by order of the East India Company's Court of Directors in London. ${ }^{56}$ However, several of its activities merit attention as they laid the groundwork for later institutional initiatives.

The Governor-in-Council apparently felt that they had to rely on the co-operation of resident European merchants and other notabilities whose political importance and independence had grown considerably of late. Thus they ordered "the Inhabitants in general [to] be summoned" which simply meant that the gentlemen of the settlement were to be assembled in the admiralty house - all Indians and plebeian Europeans were consistently excluded from such meetings. The assembly was asked to elect a committee which was to enquire into the respective matters and to suggest police regulations to the Board of Police. The five elected members consisted of three free merchants, of whom one was a former Governor of Fort St George, one a doctor and one a "covenanted servant" (Company official). At least four of them can be identified as influential creditors of the Nawab of Arcot, the formal ruler of much of the Tamil region, who strongly depended on British support. ${ }^{57}$ Though it is clearly nonsensical to call this commission

53. TNSA, Public Sundries, vol. I6, April I8 1770, pp. 34-35. See also The Compact Oxford English Dictionary, pp. 1378-I379, entry "police".

54. OIOC, MPP (P/240/29), March 2 I770, p. 177. The Board consisted of the Governor and five Council members including Warren Hastings, later Governor-General. TNSA: Public Sundries, vol. 16, March 8 1770, p. 4.

55. Cf. John Shaw (ed.), Charters Relating to the East India Company from I60o to $176 \mathrm{I}$ [...] (Madras, I887), p. 46.

56. OIOC, Madras Despatches (E/4/865), November 30 1770, pp. 43-46. The last record entry is dated March I8 I77I. TNSA: Public Sundries, vol. I6, pp. 90-9I.

57. Cf.: ibid. April I8 I770, pp. 38-39; ibid., April 25 I770, p. 4I and ibid., April 27 I770, p. 43. The committee members were Nicholas Morse, John De Fries, George Smith, Stephen Briggs and John Hollond. For prosopographical details see: OIOC, Letters and Papers of Robert Palk (IOR Neg 438I), nos 5I, 70, 179; Henry Davison Love, Vestiges of Old Madras (1913; New York, I968), vol. 2, p. 336; ibid., vol. 3, pp. 14, 402, 554; Historical Manuscripts Commission, Report on the Palk Manuscripts in the Possession of Mrs. Bannatyne of Haldon (London, I922), pp. xxii, xxxiii; Henry Dodwell, The Nabobs of Madras (London, 1926), pp. 29-30; J. D. Gurney, "The Debts of the Nawab of Arcot, 1763-1778" (unpublished Ph.D., Oxford, 1968), pp. 40, 63, 98 and Ahuja, Erzeugung kolonialer Staatlichkeit, subch. 2.4. 
"an elected body of the people" or a "people's committee" 58 it was yet more than a mere instrument of the Company's administration. Its establishment was an indication of the emergence of a colonial oligarchy which did not only consist of East India Company officials but also of entrepreneurs, professionals and, especially from the i780s, military officers. ${ }^{59}$

This committee drafted very detailed regulations concerning the wages of domestic servants, coolies and palanquin bearers which were sanctioned by the Governor-in-Council, translated into Tamil and published. Merchants were particularly interested in reducing transport costs by cutting down on coolie pay. Yet even palanquins were not merely indispensable attributes of high rank and a dignified lifestyle but also of some commercial relevance as they were employed even for long distance journeys. ${ }^{60}$ Most remarkable are those regulations aimed at consolidating labour relations:

The masters of Palankeen Bearers \& the other Tribes or Cast of Pariah Servants shall pay one Fanam monthly for each Servant to the Heads of the respective Cast, who in Consideration thereof, shall be answerable for their forthcoming[,] for any money advanced to them, not exceeding two Months Wages [...] and out of the above Allowance the Heads of the Cast shall each employ a Conicapilla [Kanakkappilla $i=$ accountant], who shall keep a Register of all such Persons employed.

Employers were only entitled to the benefits of these regulations if they paid their contribution. They were required to apply to the "Head of ye Cast" when they needed a "Pariah Servant". Master and servant both had to give one month's notice before terminating employment except in cases of dispute when "on Application to the Magistrate, the Servant will of Course receive his immediate Discharge or Dismission with such further Redress or Chastisement, as the Nature of the Case shall require" ${ }^{61}$ Four features of these regulations are most relevant as they reappear in various later regulations. First, the British notabilities sought the assistance of Indian intermediaries, namely of "Heads of Cast", even in controlling those labouring people who were, like domestic servants, under their immediate supervision. The available sources do not permit us to decide conclusively whether headmen or panchayats (caste councils) of the labourers' jatis were already in a position to control their communities effectively or whether the British notabilities were trying to invigorate or even reinvent these corporate structures. In any case, the emerging colonial oligarchy had already discovered the potential of caste organizations and leaders as intermediaries in

58. For this type of argument see D. Sadasivan, "People's Committee for Regulating Prices in Madras Two Centuries Ago", Journal of the Madras University, Section A, Humanities, 40/I (1968), pp. II5-I2O, and the same author's "The Police and the Civic Functions in Madras in Early Days", Journal of the Madras University, Section A, Humanities, 50/I (1978), pt. 2, pp. I-8.

59. I have further developed this argument in Ahuja, Erzeugung kolonialer Staatlichkeit, ch. 2.

60. Cf.: TNSA, Public Sundries, vol. 16, July 4 1770, pp. 56-6I and ibid., September 5 1770, p. 70.

6I. Ibid., July 4 I770, p. 57. 
the regulation of labour relations. Secondly, the registration of labourers by accountants was an important step towards an effective regulation of human resources by the state, which thereby obtained an instrument for labour recruitment and could supervise the fulfilment of service obligations or labour contracts. This objective was not yet realized by bureaucrats but rather by employees of the state's subcontractors (the caste headmen) who were in turn entitled to tax payments from the labourers to cover the expenses. Thirdly, the objective is discernible to make labour relations more permanent and to reduce labour mobility. Restraint was being imposed on labourers who left their masters to take up other employment in town or to seek subsistence elsewhere. Fourthly, there is the attempt to conceive disputes between masters and servants in terms of contract law to transform them into cases that could be heard by JPs. Hence the regulation admits a certain reciprocity of the legal claims of both parties, though not equality before the law: both parties had to accept a fixed term of notice, but "chastisement" was reserved for the servant - we will return to this point below. On the whole, restrictions on the termination of labour contracts were, of course, solely in the employer's interest in a period of chronic labour scarcity.

The dissolution of the first Board of Police in 177I did not end institutional intervention into Madras labour relations for that decade. In 1777, the Governor-in-Council appointed one Vira Perumal as kotwal (i.e. overseer of the market or town police superintendent). In his application letter he specified what he considered to be his future tasks. "[T]he Palanqueen Boys \&ca. wanting much to be regulated, it will be necessary for the Chief Palanqueen Boys and Chief of the Pareahs to attend daily at the Choultry Office" - this proposal was sanctioned without reservation by the Governorin-Council. ${ }^{62}$ Vira Perumal was soon facing opposition from William Webb, a British competitor for this lucrative office. ${ }^{63}$ Webb managed to be appointed "Superintendent of the Police" by the end of I780. Among other things, he promised to take care of the labour scarcity which had become a serious security issue since the Second Mysore War (I780-84) had started. ${ }^{64}$ In spite of the Court of Directors' disapproval of the office, Webb went on as police superintendent until 1784 when he suggested appointing a new committee not only to fix the prices of provisions but also to "draw out a List of the Wages proper to be given to the different Servants which will undoubtedly become the guide of every Person who wishes to promote the good of Society". ${ }^{65}$ The Governor-in-Council decided not to establish a

62. OIOC, MPP (P/240/43), March II I777, p. I87. See also ibid., pp. I84-190 and ibid., April I8 1777, p. 289.

63. Ibid. $(\mathrm{P} / 240 / 44)$, November I 1777, pp. II68-II70.

64. Ibid. (P/240/5I), October 27 I780, pp. 939-942. See also ibid. (P/240/52), March I5 178I, pp.

$255-256$.

65. Ibid. (P/240/59), June 21 1784, pp. 745-747. 
new committee but rather to continue Webb in his office which was now "Indianized" (or rather, given a Persian name) in circumvention of the Court of Directors' disapproval: the Superintendent of Police was reconverted into a kotwal. ${ }^{66}$

During these years another gentleman drafted a "Police Plan" which was far more ambitious than any other project of municipal administration in eighteenth-century Madras. ${ }^{67}$ "The Grand objects of a General Police are to promote Health and to prevent Impositions and Fraud", wrote Stephen Popham, ${ }^{68}$ an Anglo-Irish lawyer and former MP who had left Europe after bankruptcy. His plan dealt with various issues including the registration of inhabitants and visitors, the lighting, cleaning and repair of streets, the control of liquor shops and pubs, the supervision of jewellers and other shopkeepers, the regulation of markets, the fixing of food prices and, of course, of wages. Popham claimed his scheme would benefit the "community at large"; it represented "the wishes of the public", was "of the first rate importance to every Inhabitant in Madras" and for the "real improvement of that Colony". ${ }^{69}$ What constituted and styled itself as the "community", "public", "inhabitants" or "colony" of Madras in these years was, in fact, no more than the European oligarchy. This is clarified in a 1786 petition of 205 European notables in support of Popham's scheme who introduced themselves as "We the Inhabitants of Madras and Environs". They insisted in particular on the speedy implementation of measures concerning the regulation of prices and wages. They spelled out against whom the "community's" interests had to be defended, namely against "dealers of provisions", servants, artisans, labourers, coolies, robbers and thieves who were thus summarily excluded from that community of inhabitants. ${ }^{70}$ What was asserted to be the pursuit of public interest was the oligarchy's claim of domination over the majority of the city's inhabitants on grounds of social superiority and by right of colonial conquest.

The European notables' pressure succeeded in that the Governor-inCouncil appointed a "Committee of Police" consisting of a colonel, of several "covenanted servants" and of private entrepreneurs of British, Portuguese and Armenian origin to examine Popham's Police Plan and to recommend practical measures..$^{71}$ Among other things, they suggested that

66. Ibid. (P/240/64), August 5 1786, p. 1346.

67. This plan, dated January I2 I782, was entered into the council's records only in I786: ibid. (P/240/63), May I2 1786, pp. 638-663; excerpts were published in Love, Vestiges of Old Madras, vol. 3, pp. 309-313.

68. OIOC, MPP (P/240/63), May I2 1786, p. 639.

69. Ibid. (P/240/62), May I2 I786, pp. 582, 577, 554 (Popham to Governor-in-Council, December

I6, I785) and ibid. (P/240/63), May I2 1786, pp. 638-639.

70. Ibid., pp. 663-670.

71. Ibid., May I8 1786, pp. 697-699. The designation "Committee of Police" appears ibid., July I3 I786, pp. II24, II33. 
the Governor-in-Council exerted their authority to reduce wages in order to restore the proportion of wages and food prices to the standards before the Second Mysore War. The pay of domestic servants and of coolies was to be fixed by a permanent police board while the regulation of artisan rates was to be left to the discretion of the Committee of Works. ${ }^{72}$

Accordingly, a permanent "Committee of Regulation" consisting of kotwal William Webb, two other covenanted servants, Stephen Popham and two European "free merchants" was appointed in August I786 "for the purpose of fixing the Wages of Servants[,] the prices of Provisions, and for preserving the Cleanliness in the Black Town" ${ }^{73}$ They decided to regulate wages first as immediate progress could here be achieved "to the general convenience of all ranks of People" ${ }^{74}$ However, the "Heads of the different Casts of Palanquin bearers" were not prepared to collaborate when they were summoned to explain the current "extravagant" rates: "[t]ho[ugh] repeatedly required to give some answer they pointedly avoided giving one or making any proposition whatever". The committee finally determined different rates for four "Casts" of Madras palanquin bearers, a sizeable occupational group of about 2,00o men. ${ }^{75}$ The numerous "Gentoo Boys" (members of the boyi caste from the Andhra coast) received higher wages than the "Malabars" (caste Tamils), "Paryars" ("untouchable" paraiyars) or the "Madras Gentoos" (Telugu speakers of Madras). So-called "Head boys" were to play a similar role in the regulation of labour relations as the "Heads of the Cast" according to the orders of 1770. The foremen of all gangs of six to eight bearers were required to pay a fanam per month to these "Head boys" who were appointed by the Committee of Regulation and could in turn be made liable if palanquin bearers did not turn up for service or disappeared before having worked out advances from their employers. They were also obliged to keep a register of all foremen and bearers. ${ }^{76}$ The committee encountered, moreover, another problem when dealing with palanquin bearers:

We find that the Gentoo Boys object in most families to do any sort of House work under a pretence that it is incompatible with their Religion, there is nothing which has subjected Europeans to more impositions than their ignorance of the real customs which the Religious Principles of different Tribes of Indians have attached to their casts, when from a dread of encroaching on their prejudices they give implicit faith to the assertion of the native. It shall be our care to discover and expose this species of imposition as often as we can and since we understand that the Gentoo Palanquin Boys at the northern Settlements do the same House

72. Ibid., pp. II27, II38-II39.

73. Ibid. (P/240/64), August 5 1786, p. 1346.

74. Ibid., August 2I 1786, p. I570.

75. For the size of that occupational group cf. Neuere Geschichte der Evangelischen MissionsAnstalten zu Bekehrung der Heiden in Ostindien, 38th Stueck (Halle, Saxony, 179I), p. 173.

76. OIOC, MPP (P/240/64), October 20 1786, pp. 1994-1997. 
work which the Malabars or Paryars do at Madras we recommend that the like be expected from them here. ${ }^{77}$

Here is an early acknowledgement of the value of anthropological knowledge as an instrument of colonial domination. At the same time, we learn that the relevance of the "idiom of caste" in negotiations with the British was not only understood by plebeian social groups but also actively made use of; communities like the boyis sought to defend and/or invent customs and traditions that legitimized certain rights. ${ }^{78}$

The Committee of Regulations turned next to the regulation of coolie wages as "every individual in the community, but more particularly the Merchants, were so much interested" in that subject. Hence they asked the city's "principal merchants" to inform them about the rates paid to coolies since I772 - a request readily granted not only by prominent British, Portuguese and Armenian entrepreneurs but also by "native merchants of consideration". These Indian notables were thus not totally opposed to interventions in labour relations on the part of the emerging colonial power and may even have expected these interventions to be more advantageous than preceding modes of subordinating labour. Other regulations determined the rates of cart hire and the pay of domestic servants. All complaints as to the "misconduct" of palanquin bearers, coolies, domestic servants, carters and other labourers were to be referred to the Committee of Regulation, which was thus also vested with jurisdictional powers in labour matters. ${ }^{79}$ This time, the Court of Directors was rather pleased with the Madras attempts at policing the poor. ${ }^{80} \mathrm{How}-$ ever, after about two and a half years the Committee of Regulation appears to have been defunct, probably due to lack of funds. ${ }^{81}$

In 1797, Lord Hobart appointed another Committee of Police because of "[t]he inconvenience generally felt, and complained of, by the Resident Inhabitants of Madras, for want of established Regulations respecting the price, and sale of provisions, the Wages of Artificers, Palankeenboys, Coolies \& other description of Labourers". The Committee now consisted of administrators and army officers, some of whom had considerable business interests apart from their Company covenants or commissions. Hobart

77. Ibid., pp. 1998-1999.

78. The boyis' oral epic Kamamma Katha also deals with conflicts between the community and the East India Company on matters of caste status. Cf. Velcheru Narayana Rao, "Epics and Ideologies: Six Telugu Folk Epics", in Stuart H. Blackburn and A. K. Ramanujan (eds), Another Harmony, New Essays on the Folklore of India (Berkeley etc., 1986), p. I39.

79. OIOC, MPP (P/240/64), October 20 1786, pp. 1998-2005, 2008 and ibid., November 3 1786, p. 2010.

80. Cf. OIOC, Despatches to Madras (E/4/873), July 3I I787, \$57, p. 68I and OIOC, MPP (P/ 24I/4), February 3 I788, p. 447.

8I. Cf. OIOC, MPP (P/24I/7), September 23 I788, pp. $2365-2366$ and ibid., (P/24I/Io), January 2 I789, pp. 47-48, 5I-53. However, H. D. Love assumed that the implementation of Popham's

"Police Plan" ended only in I79I when the office of kotwal was discontinued for some years; Love, Vestiges of Old Madras, vol. 3, p. 48I. 
ordered them to take stock of earlier experiences in dealing with such issues and referred them specifically to the records of the late Committee of Regulation and to the police regulations established by the French in Pondicherry. He cautioned the Committee not to interfere "in a Summary and Arbitrary manner" with "questions regarding the Casts and Customs of Natives". Again support was sought from the gentlemen of the settlement, who were assembled in the Madras Exchange and who agreed to cover the Committee's expenses of 400 pagodas (about $£ \mathrm{I} 60$ ) per month by way of voluntary contributions. Hence the Committee depended precariously on the European notables' goodwill. However, its activities continued at least until the turn of the century. ${ }^{82} \mathrm{~A}$ small administrative apparatus was created consisting of two British administrators, an Indian kotwal and fifteen other employees. ${ }^{83}$

Though this committee's activities seem to have rather focused on the reduction of food prices, ${ }^{84}$ labour relations and wages were also regulated, much on the terms of Popham's Committee of Regulation. In this respect, the most contentious issue was the pay of palanquin bearers who were apparently rather self-confident and efficient in their negotiations with employers. ${ }^{85}$ The reasons are partly disclosed in a 1799 report of the Committee concerning that "Class of people [...] against whom repeated Complaints are daily exhibited for extortion and misbehaviour to the great distress of the Public":

As since they have been employed with the Army they have held themselves no longer under our authority we therefore hope for the public Benefit, that we may be authorized to put the Regulations in full force and that not a Pallanqueen Bearer who does not conform to the established rates and mode of hiring may remain in the Settlement except those actually on military service [...] We are fully aware that some temporary inconvenience will arise upon the first Publication of the order by a Partial desertion of the Boys, but we think it will soon subside, when it is discovered that such Order cannot be evaded. ${ }^{86}$

The palanquin bearers had obviously been able to take advantage of the Company's enhanced transport requirements during the Fourth Mysore War earlier that year and had learnt how to play off the administration's departments against each other. The emergence of a clear-cut group of intermediaries or recruitment entrepreneurs consisting of a "Dullavoy"

82. Cf. Love, Vestiges of Old Madras, vol. 3, p. 486. See also TNSA, Public Consultations, vol. 238B, August 27 I799, p. 3053.

83. The preceding paragraph refers to: OIOC, MPP (P/242/I), December I 1797, pp. 3744-3748, 3752-3753; ibid., December 22 1797, pp. 4059-4061; ibid., December 29 1797, pp. 4I46-4159 and TNSA, Public Sundries, vol. 61, December 20 1797, pp. 5-13.

84. Cf. TNSA, Public Sundries, vols. 6I and 64, passim. See also OIOC, MPP (P/242/4), May I8 1798, pp. I319-1330, I338-I342 and ibid. (P/242/5), June I5 I798, pp. I782-1807.

85. Cf. TNSA, Public Sundries, vol. 64, pp. 33-40. See also ibid., vol. 6I, p. I9.

86. TNSA, Public Consultations, vol. 238B, August 27 1799, p. 3054. 
(dalawai $=$ "commander") and twelve "Maistry Palankeen Bearers" ${ }^{87}$ may also have had effects other than those intended by the early colonial administrators when they created these offices. As in the case of the boat maistries (foremen), which I have discussed elsewhere ${ }^{88}$ these intermediaries could have quite efficiently pursued their own interests which collided at times with those of their British masters. However, when the south Indian wars ended with the destruction of the Mysore sultanate in 1799 and when an early colonial regime (which has been characterized adequately as "military despotism" $)^{89}$ had successfully established itself in much of the peninsula, the labouring people's chances to withdraw from British authority and seek protection and subsistence elsewhere were reduced and, consequently, their negotiating powers too.

To conclude this section, three points should be emphasized. First, the repeated attempts at creating a police system always included the regulation of labour relations and wages. Secondly, there was a continuity of methods by which European notabilities tried to reduce their dependency on Indian intermediaries whose services continued, however, to be essential. Thirdly, the institutional forms developed for these purposes remained semigovernmental in character. On the one hand, they were attached to the East India Company's administrative apparatus and depended on the Company's legitimacy and coercive potential for their efficiency. They were, on the other hand, never fully integrated into the governmental apparatus in this period as the Company could solve its most urgent labour problems through other institutional structures such as the Committee of Works. The legality of "committees of police" remained doubtful until the Charter of I793, which is why they depended fully on the European oligarchy's good will and developed discontinuously. By the end of the century, however, not only did the efficiency of such regulative measures increase but also the colonial administrators' readiness to intervene openly in the country's social relations.

\section{"NOLUMUS LEGES ANGLIAE MUTARI": ENGLISH LAW AND EARLY COLONIAL REGULATION OF LABOUR RELATIONS}

Michael Anderson has argued that early Company administrators could take recourse to "ideologies of family, land, and caste" that had been "used by pre-colonial rulers to manufacture consent for highly coercive labour processes". Hence, he infers, there was no "policy featuring labour as a separate topic deserving state regulation" in that period and the "numerous legal

87. TNSA, Public Sundries, vol. 64, p. 33-37.

88. Ahuja, Erzeugung kolonialer Staatlichkeit, ch. 3.

89. Bayly, Indian Society and British Empire, pp. 79, 84-89. 
techniques for regulating the labour market" that had been developed in Britain were not applied in India - a circumstance he regards as "almost incredible" himself. ${ }^{90}$ As to eighteenth-century Madras, pre-colonial forms of subordinating labour could be and were indeed utilized by the Company and European entrepreneurs. Anderson is right in his assumption that the organizational structures of caste could function as particularly effective instruments for recruiting and controlling labour. ${ }^{\text {II }}$ The preceding section indicates, however, that this neither precluded labour being considered a "separate topic deserving state regulation" by British notabilities nor the intervention into the social organization of labour on the part of legal and administrative institutions like JPs or Police Committees. Anderson is equally mistaken as to the application of British "legal techniques for regulating the labour market". The Company's labour requirements in late eighteenthcentury South India were so pressing and labour power had already been commodified to such an extent that the regulation of the labour market necessarily appeared on the administrators' agenda..$^{92}$ Moreover, Company officials and other "gentlemen" often derived their notions of social order as well as the measures to maintain it from English law which they considered to be one of their nation's greatest achievements: "Nolumus leges Angliae mutari" ("We do not wish England's laws to be changed") was the motto of the late eighteenth-century weekly Madras Courier. ${ }^{93}$ This section will try to demonstrate that contemporary British law served as an ideological tool-kit when British notabilities tried to work out effective methods for regulating the Madras labour market.

In I8II detailed "Police Regulations", many of which dealt with wages and other labour issues, were established, registered at the Madras Supreme Court of Judicature and printed. ${ }^{94}$ This seems to have been the colonial regime's first attempt at codifying labour law in south India which was, however, still confined to the Presidency town. These ordinances were, as far as we can identify their sources at present, ${ }^{95}$ derived from English legal ideas and laws originating from before the nineteenth century. They are the more valuable for the study of the preceding decades as they placed on record systematically what had already been the guiding principles when JPs or members of police committees settled labour cases in the late

90. Anderson, "Work Constructed", pp. 90-91.

91. Cf. Ahuja, Erzeugung kolonialer Staatlichkeit, ch. 5.

92. For a discussion of these issues see ibid., chs 4, 5 .

93. Madras Courier, vols I793-I795.

94. For the legal background of these regulations see Shaw, Charters Relating to the East India Company, p. 80.

95. Systematic research is necessary in this field. A promising comparative project seems to be under way; cf. Paul Craven and Douglas Hay, "Master and Servant in England and the Empire: A Comparative Study", Labour/Le Travail, 3I (1993), pp. 175-184 and "The Criminalization of 'Free' Labour: Master and Servant in Comparative Perspective", Slavery and Abolition, I5 (1994), pp. 7I-IOI. 
eighteenth century. We will, therefore, discuss the five regulations dealing with labour issues in some detail.

The "Regulation for apprehending and punishing idle and disorderly Persons" ${ }^{\prime \prime 6}$ classified those as "Rogues and Vagabonds" who answered one of the following descriptions:

(i) persons without means to support themselves who lived "idle without employment" and refused to work;

(ii) coolies and labourers who refused "to work for a reasonable hire";

(iii) street beggars;

(iv) persons without permanent abode lodging in punch houses etc. who could give no "good account" of themselves;

(v) persons "of suspicious characters";

(vi) persons without "any visible honest means of subsistence" such as gamblers;

(vii) persons who had "run away from their service";

(viii) "persons using any subtle craft to deceive and impose on others"; and, finally,

(ix) "persons" who defected their wives and children.

"Idleness" and "disorderliness", "roguery" and "vagabondage" were in this regulation thus very loosely defined offences every labourer could be indicted for who left his employment without his employer's consent, who refused to do a certain type of work, refused to work for a certain master or to accept a remuneration appearing "reasonable" to the judges. Furthermore, various other forms of "aberrant" behaviour were declared illegal, particularly modes of subsistence without master, without work, without permanent abode. This regulation reproduced the pattern of the numerous English vagrancy acts (twenty-eight were decreed between I700 and I824 alone) which were thus transferred to another social context. As in England, they served to discipline labourers and restrict their mobility. ${ }^{97}$ As in England, "suspicious" behaviour was sufficient for conviction..$^{98}$ The provision declaring the desertion of families by husbands an offence suggests that this Police Regulation may have been a very close copy of an English law. This provision made sense only in England where parishes had to support deserted wives and children according to the Poor Law. ${ }^{99}$ Not so in Madras where, as elsewhere in India, colonial administrators generally did not accept any responsibility for the subsistence of the poor ${ }^{\text {roo }}$ and would not even have known whether husbands left or stayed with their families in the Black Town or a Madras suburb. The regulation determined the penalty for

96. TNSA, Military Sundries, vol. I39, "Police Regulation, No. I".

97. Cf. Rogers, "Regulation of Labour in Britain", pp. IO4-IO6.

98. Cf. Rogers, "Policing the Poor in London", pp. I3I, I45.

99. Cf. Rogers, "Regulation of Labour in Britain", p. I02.

Ioo. Cf. Ahuja, Erzeugung kolonialer Staatlichkeit, pp. 297-299. 
"vagabondage" to be up to three months of "hard labour" on public roads, in case of recidivism the convict would be deemed an "incorrigible rogue" and punished with up to six months of forced labour and no more than two dozen lashes. Defendants could be sentenced summarily by a single JP. The specific circumstances of the emerging colonial metropolis were considered in that there was a provision which exempted unemployed sepoys, soldiers, and sailors from this regulation if they could produce certificates from their superiors as the Company was strongly interested in a freely disposable labour reserve in respect of these occupational groups.

"Police Regulation No. 3 " ${ }^{\text {"or }}$ was aimed at the "immediate summary punishment" "of dishonest practices, of the misconduct of servants, of riots and affrays, and of other violations of the public peace and good order". The provisions concerning labour issues read as follows:

All servants and all workmen, Lascars or other hired to work in any employ who shall refuse to work or shall desert their employ or wilfully disobey or behave disrespectfully or insolently to their Masters or Mistresses, employers or lawful superiors or who shall neglect their duty, shall be subject, at the discretion of the Magistrates, to whipping not exceeding 2 dozen of stripes and hard labour for a period not exceeding four months, or either of those punishments on conviction before two Magistrates. [...] Any Servant who shall leave his or her Master or Mistress without permission and giving one month's notice, shall be deemed and taken to have deserted such employ. [...] Any Master or Mistress [...] who shall illegally punish his or her servants, or who shall refuse to pay his or her servants wages within fifteen days after the same shall have become due, shall be subject to a fine not exceeding 20 Pagodas.

These provisions took their pattern from contemporary English labour law in the narrower sense. The so-called "master and servant law", consisting both of statute and case law, defined, according to Paul Craven and Douglas Hay, "the terms of the individual contract of employment [...], and was distinguished by the use of penal sanctions, notably imprisonment, for breach by the servant (but not the master)" ${ }^{102}$ Originating from the fourteenth century, it remained in force in modified form until 1875. In essence, it assumed a fundamental inequality of employer and employee before the law, though the labourer's subordination as a person was limited as certain legal claims on the employer were conceded to him. "Police Regulation No. 3 " was accordingly directed against the "misconduct of servants", not against that of masters who were, however, bound to perform certain contractual obligations. What might be called an "asymmetric reciprocity" between "master" and "servant" was thus sanctioned by law and, like in England,

IOI. TNSA, Military Sundries, vol. I39, "Police Regulation, No. 3".

102. Craven and Hay, "Master and Servant in England and the Empire", p. 175. See also Daphne Simon, "Master and Servant", in John Saville (ed.), Democracy and the Labour Movement (London, 1954), p. 198. 
reflected in the penal regime. ${ }^{103}$ Only a "servant" could be sentenced to confinement, forced labour and corporal punishment. A master could only be fined for not performing his contractual obligations - his body was taboo, for equal degrees of punishment would have undermined his authority. This background of legal ideas helps to explain the already mentioned police regulations of 1770 and 1786 which provided only for misconduct of labourers and reserved chastisement for them, too. "Misconduct" - this conveniently imprecise delinquency - is repeatedly mentioned in the records, for example, in respect of a band of palanquin bearers who escaped from the "Town Poligar's" gaol in 1799 to which they had been confined "as a punishment for misconduct". ${ }^{104}$ It is important to note that these measures were neither erratic cases of arbitrariness nor specifically colonial forms of enforcing authority: they were fully consistent with a contemporary "gentleman's" ideas of lawfulness and with the practice of incarcerating "insubordinate" labourers in England. ${ }^{\text {10 }}$

"Police Regulation No. 3" of I8II empowered the Madras JPs to try labour cases between the quarter sessions in summary proceedings which only some of the judges were required to attend. This was no innovation. There is evidence even from 1770 that the magistrates dealt with matters of "police" (explicitly including labour issues) whenever the occasion afforded it. ${ }^{\text {I06 }}$ Legal procedure in cases of master and servant law was informal in England too. This implied that generally no records were kept and the judges' freedom to interpret law to their own taste was fairly unlimited. ${ }^{107}$ Correspondingly, the eighteenth-century JPs in Madras have left behind only a fragmentary set of their quarter session proceedings. ${ }^{108}$ Their judgements in cases concerning labour issues left but few traces in the records, though we can assume that they will usually have been in accordance with contemporary master and servant law.

However, the provisions for corporal punishment of "Regulation No. 3" contrasted strikingly with the contemporary penal regime in England. Paul Craven and Douglas Hay have observed that whippings were probably not inflicted as punishment for master and servant offences in England after the seventeenth century and that the last law providing explicitly for such corporal punishment was the Statute of Artificers of $1562 / 3$. Yet they point out at the same time that this type of punishment remained typical for British

I03. Cf. Simon, "Master and Servant", pp. I60, 195-199; Craven and Hay, "Criminalization of 'Free' Labour", p. 82 and "Master and Servant in England and the Empire", pp. I79-I8o.

I04. TNSA, Public Consultations, vol. 238B, August 27 I799, p. 3053.

I05. Cf. Craven and Hay, "Criminalization of 'Free' Labour", p. 88.

I06. OIOC, MPP (P/240/29), March 2, I770, p. I74.

I07. Craven and Hay, "Master and Servant in England and the Empire", p. I8o and "Criminalization of 'Free' Labour”, p. 72.

I08. TNSA, Quarter Sessions, vols I-3, 6, 8, I2, I3. (These unique and invaluable sources of social history were in a state of decay and urgently required restoration early in 1997.) 
colonies in later periods: for those in North America as for Ireland and the Caribbean islands, and from the mid-nineteenth century, also for those in Africa and Asia. ${ }^{109}$ Our material suggests that this applied equally to early colonial South India. In eighteenth-century Madras, corporal punishment of labourers by their employers or supervisors seems to have been a regular feature of various types of labour relations including those of domestic servants as well as those of stevedores employed by the Company. Labourers were whipped or caned with the sanction of the Governor-in-Council as well as at the discretion of private employers. There seem to have been no doubts concerning the legality of these practices except when employees died on account of these chastisements. ${ }^{\text {IIO }}$ As late as 1796 it was stated for the first time by a Governor of Fort St George that punishments merely based on the employer's authority were illegal. This was declared during a trial against an Indian merchant who had had one of his palanquin bearers battered to death. "II "Police Regulation No. 3 " of I8II should be understood as a step towards the rationalization of corporal punishment which from now on was to be inflicted with the sanction of government only. On the whole, the preference of corporal punishment to confinement has to be regarded as a specifically colonial feature of British labour jurisdiction in this period though it should be added, for the benefit of eulogists of pre-colonial "innocence", that severe corporal punishment and torture had also roots in penal regimes of immaculately indigenous origin. ${ }^{\mathrm{II}}$

The authors of "Police Regulation No. 7 " of $18 \mathrm{II}^{\mathrm{II3}}$ clarified that the regulation of wages and working hours was essential for the enforcement of an obligation to work and for restraining labourers to discipline:

$[\mathrm{F}]$ or preventing habits of idleness and dissipation among labourers and others, as well as the inconvenience to the public from exorbitant wages and similar exactions, it is expedient that the wages [...] should be fixed by lawful authority, and also the hours during which such labourers and others should be compelled to work [...].

Thus the "Superintendent of Police" was authorized to regulate the wages of coolies, day labourers, artisans, palanquin bearers, carters and other "work men”. All disputes concerning wages were to be determined either by the Superintendent or by the sitting magistrates. Masters who paid more than the fixed rates risked a fine not exceeding ten pagodas. Labourers who

I09. Craven and Hay, "Criminalization of 'Free' Labour", pp. 83-89.

IIO. Examples are given in Ahuja, Erzeugung kolonialer Staatlichkeit, subchs 3.4, 3.6, 3.7, 5.4, 5.5. III. TNSA, Quarter Sessions, March I2 I796, pp. 85-86.

II2. For a contemporary case of torture in the Madras hinterland by one of the nawab's Hindu tax-collectors see OIOC, MPP (P/240/50), May I9, I780, p. 286. For South Indian torture techniques see also Edgar Thurston, Ethnographic Notes in Southern India (Madras, 1906), pp. 407-432. For a study of a pre-colonial "culture of punishment" see Sumit Guha, "An Indian Penal Regime: Maharashtra in the Eighteenth Century", Past and Present, I47 (I995), Pp. IOI-I26. II3. TNSA, Military Sundries, vol. I39, "Police Regulation, No. 7". 


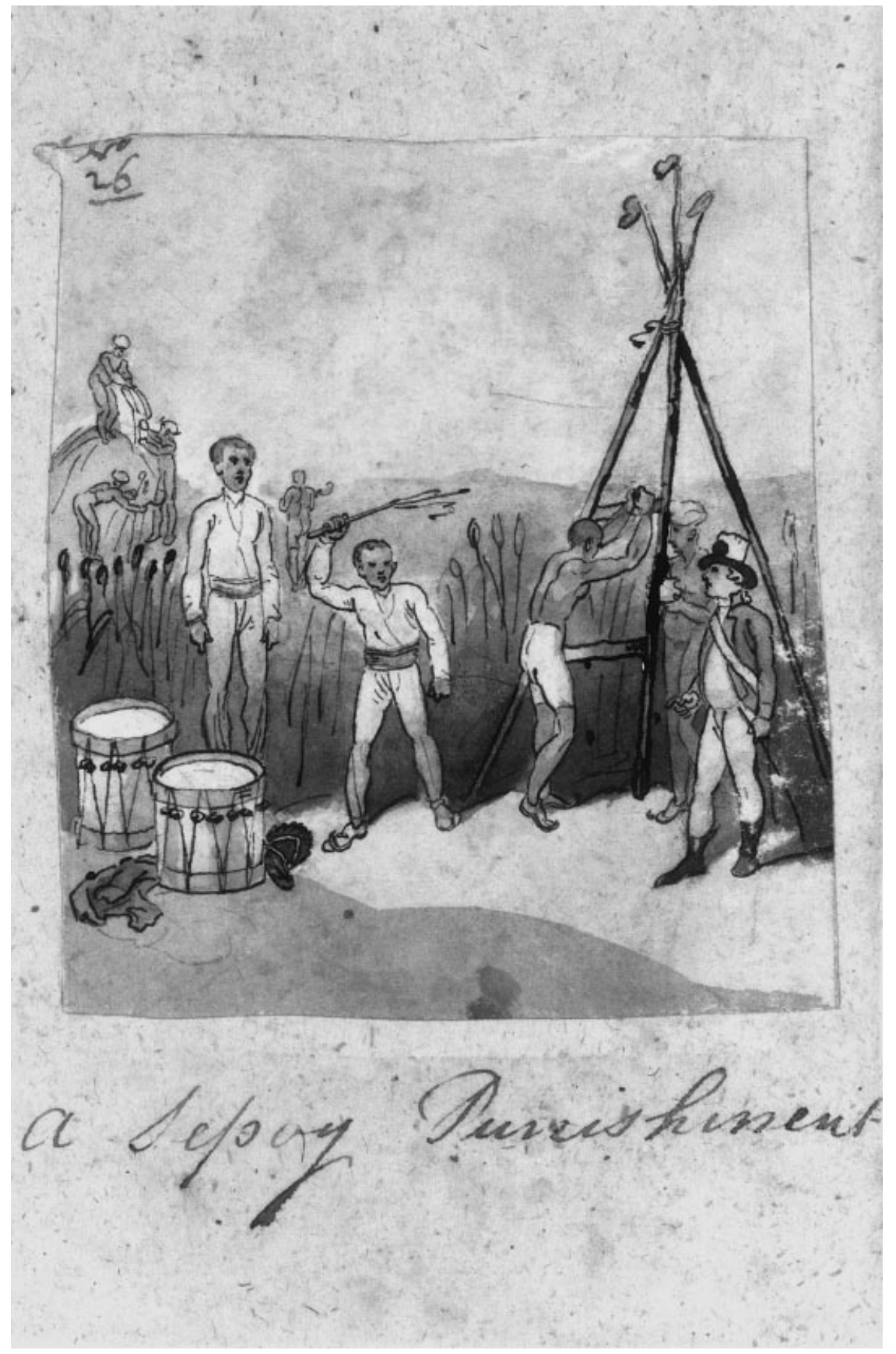

Figure 3. Robert Mabon, "A Sepoy Punishment", c. 1792. Watercolour over pencil. Yale Center for British Art, Paul Mellon Collection 
demanded higher wages from their employers could be sentenced to a fine up to five pagodas or to corporal punishment not exceeding a dozen lashes. Another provision of that regulation apparently served to criminalize labour disputes. Any person who prevented or tried to prevent others from working was liable to a fine not exceeding twenty-five pagodas or, on non-payment, to up to two dozen lashes. Claims of such offenders to an "exclusive or superior right to be employed in such work" were to be disregarded. It is clear that this provision aimed at "instigators" of collective forms of labour protest. Furthermore, the repudiation of claims of superior rights to employment suggests that the administrators here tried to cope with the endeavours of certain jatis or occupational groups to keep "outsiders" out of their business. ${ }^{\text {II } 4}$ Another regulation tried to impose control on "head men" of all kinds of artisans and labourers. All these middlemen were from now on to be registered which was at least partly due to the fact that they often played a crucial role in labour disputes. This is clarified by a provision making every maistry or "head man" liable to a fine not exceeding ten pagodas who was convicted "of secreting any artificer or cooly being idle and not in employment, in order to prevent their being legally employed in the public service, or by individuals" "II Earlier regulations had, as demonstrated above, also held these intermediaries responsible for their subordinates' attendance at work. This was simply another attempt on the part of the Governor-inCouncil to enforce their opinion as to which maistries were neither free recruitment entrepreneurs nor representatives of a group of labourers but merely the Company's paid servants, for the purpose of forcing labourers to work for fixed wages. Further research would be required to ascertain whether they were more successful in this respect than their eighteenthcentury predecessors. ${ }^{116}$

"Police Regulation No. 8 "117 was concerned with a particular occupational group which had already been the object of much administrative effort since the I750s; it aimed at "the summary and immediate punishment of all frauds and other offences committed by the Boatmen of Madras". The Master Attendant was granted the power to adjudicate all cases concerning delinquencies of stevedores summarily and to inflict punishment on those convicted - an authority he had been given once before by a Council's ordinance in $1797 .{ }^{118}$ The JPs were only to be involved in these cases if requested

II4. A conflict of this type is recorded for 1782 between "boat maistries" (superiors of stevedores) belonging to different communities. See esp. OIOC, MPP (P/240/55), December 3 1782, p. I332. See also Ahuja, Erzeugung kolonialer Staatlichkeit, subch. 3.6.

II5. TNSA, Military Sundries, vol. I39, "Police Regulation, No. 5".

II6. The role of maistries as recruitment entrepreneurs is discussed in Ahuja, Erzengung kolonialer Staatlichkeit, ch. 3, which is a detailed case study of the labour relations of stevedores in late eighteenth-century Madras harbour.

II7. TNSA, Military Sundries, vol. I39, "Police Regulation, No. 8".

II8. OIOC, MPP (P/24I/70), February 24 I797, p. 585; ibid. (P/24I/73), June 22 1797, pp. 20822083 and ibid., June 24 I797, pp. 2II3-2II4. 
for assistance by the Master Attendant. Hence this colonial officer held the almost unrestricted authority to discipline his labour force not only as a supervisor or employer but also in his capacity as the competent judge. "Affray or breach of the peace" was among the delinquencies that were to be suppressed - another provision which could serve as a convenient legal device to criminalize labour disputes. The regulation's main goals become evident in the following passage:

Every boatman [...] who shall [...] be convicted of fraudulently embezzling, cutting up or destroying, unduly possessing, or wilfully or carelessly injuring [...] any article or goods [...] or of not fully delivering all such goods as shall be intrusted to him or them, and all and every person duly convicted [...] of aiding and abetting those frauds or abuses [...] shall be subject to fine, not exceeding 20 Pagodas and to hard labour on the roads not exceeding 6 months and to corporal punishment not exceeding four dozen of stripes or any, or either of those punishments [...].

"Embezzlements" committed by stevedores during the shipment of goods had been on the agenda of Governors-in-Council for decades. ${ }^{\text {II }}$ This regulation was another, probably equally futile attempt to cope with this problem - even half a century later it was stated that the merchants' profits were reduced by up to twenty per cent by manipulations on the part of the Madras boatmen. ${ }^{\text {I2O }}$ The issue's importance in I8II is indicated by the penalties provided for in the regulation, which were much more severe than those for vagrancy or master and servant offences. The penal offences' detailed description permits some insight into the nature of that perennial conflict embezzlement and wilful damaging of merchandise seem to have been the principal offences. However, what appeared to be a crime in the eyes of a British merchant was not necessarily one from a stevedore's point of view the bounds were rather blurred between petty theft and the appropriation of a customary share, between wilful damaging of grain bags and a customary claim to that part of the freight which had become wet during shipment and could thus not be sold anymore. This was so even in eighteenth-century London where, on the one hand, thousands of stevedores were sentenced for "embezzlement" while, on the other, most of them received only little pay or even none at all as it was generally assumed that they would appropriate a share of the goods as legitimate "perquisites". ${ }^{221}$ In Madras, European administrators and traders had also acknowledged that the appropriation of small proportions of the merchandise could not be avoided when the boatmen's wages were low. ${ }^{\text {I22 }}$ Furthermore, as I have argued elsewhere, a combi-

II9. Cf. Ahuja, Erzeugung kolonialer Staatlichkeit, subchs 3.4, 3.5, 3.7.

120. C. G. Armstrong, "Madras Harbour. Its History and Development", The Journal of the Madras Geographical Association, 5/I (1930), pp. I8-I9.

I2I. Cf.: Peter D'Sena, "Perquisites and Casual Labour on the London Wharfside in the Eighteenth Century", London Journal, I4/2 (1989), pp. I30-I47.

I22. Cf. Ahuja, Erzeugung kolonialer Staatlichkeit, subchs 3.4, 3.5. 
nation of money wage and kind was the typical compensation for labourers in the rural hinterland of Madras and, consequently, in the city itself. ${ }^{123}$ "Police Regulation No. 8" was thus located in a legal space where the issues of labour and property intersected; it defined, from the colonial oligarchy's perspective, distinctions between lawful allowances and fraudulent appropriations. Ultimately, the regulation criminalized perquisites which customarily constituted a considerable proportion of a stevedore's income.

The "Police Regulations" of I8II are particularly relevant for our study as they enable us to perceive more clearly those legal techniques obtained from "the laws of England" which the gentlemanly community of South India's emerging colonial metropolis did not wish to be changed and which they adopted for regulating wages and labour relations in Madras. They permit us to identify those ideological procedures by which the concrete problems of the world of labour in Madras could be transformed into "facts" that could be dealt with from a legal point of view. More specifically, we can make out how modes of behaviour of the "labouring poor" that conflicted with the colonial oligarchy's interests were now classified as (i) vagrancy, (ii) master and servant offence, or (iii) offence against property. The institutional measures the Governor-in-Councils of Fort St George took recourse to remained very much the same throughout the latter half of the eighteenth century in spite of recurrent interruption and failure. This is not only due to the persistence of the problems themselves but also to the fact that British administrators always referred to the same "archive of legal techniques". The various measures of the various Madras Police Committees as outlined in the preceding section should, therefore, be understood as experiments in the application of well-established techniques of domination to a new social context, i.e. as colonial institution-building.

In most cases this application remained implicit as the legislative and jurisdictional competencies of the Company's administration remained fairly limited before the I790s. However, the Anglo-Irish lawyer Stephen Popham's expert opinion concerning the legality of his Police Plan found its way into the Governor-in-Council's records a decade earlier. In this memorandum he had particularized what he considered to be the "law authorities" legitimizing his scheme. As to the regulation of wages, Popham referred to following excerpts from various statutes: ${ }^{124}$

(a) 20[th year of the reign of] George II [I746/47], chapter I9, section 3: "If an[y] Servant[,] Artificer[,] Handecraftman or other labourer shall misbehave in his Employment, Commit to the House of Correction there to remain and be Corrected \&c. Justice to examine upon Oath and

I23. See ibid., subchs 5.2, 5.6.

124. For the quoted passages of Popham's legal opinion see OIOC, MPP (P/240/63), May I2 1786, pp. 634-636. 
make order for Payment of wages, the Persons aggrieved may appeal to Quarter Sessions."125

(b) 6 George III (I765/66), c. 25, s. 4 \& s: "Labourers or others not fulfilling their Contract or being guilty of an other misdemeanor to be Committed to the House of correction." ${ }^{26}$

(c) 2 \& 3 Edward VI (I548-50), c. I5, s. I.3: "Artificers or Workmen conspiring the time or manner of their work forfeit $\mathfrak{E}_{\mathrm{IO}}$ first Offence \&c." ${ }^{127}$

(d) $I 7$ George II (I743/44), c. 5, s. I: "Disorderly and idle persons to be committed to the house of Correction." ${ }^{128}$

(e) s Elizabeth (Is62/63), c. 4, s. Is: "Justices of the Peace calling unto them such discreet and grave persons as they shall think meet and conferring together respecting the plenty or Scarcity of victuals \&c. have authorized to limit rate and appoint the wages of all Labourers, Artificers workmen and apprentices \&c. as they shall think meet by their discretion to be rated \&c. by the year or by the day week, month or otherwise[,] with meat and drink or without \&c. \&c." ${ }^{129}$

What were the implications of these provisions? First of all, they authorized Justices of the Peace to determine wages (e) and to enforce the payment of these rates (a). Popham referred explicitly to the famous Elizabethan "Statute of Artificers" former and particularized its implementation. It should be noted, that regulations for fixing wages in general (as opposed to the determination of wages in specific occupational sectors) had become rather uncommon in England by then. ${ }^{131}$ Adam Smith had welcomed this development. ${ }^{132}$ F. M. Eden had argued that such regulations only held good in respect of agrarian labourers. ${ }^{133}$ In Madras, however, Popham, like most other British notables, sought to establish as comprehensive a regulation of wages as possible.

Secondly, these "law authorities" implied a general prohibition of any combination on the part of labourers. Here Popham relied again on a Tudor statute (c) which seems to have been occasionally also referred to in contemporary England when labour disputes were suppressed. ${ }^{134}$

125. See also for this law Eden, The State of the Poor, vol. I, pp. 292-294.

126. See also ibid., vol. 3, p. cclx.

I27. See also ibid., vol. 3, p. ccxliv and John V. Orth, "The English Combination Acts Reconsidered", in Snyder and Hay, Labour, Law, and Crime, p. 134, nn. 39, 4I; p. I44.

128. This law is summarized in Eden, The State of the Poor, vol. I, pp. 306-310.

I29. See also ibid., vol. I, pp. I24-I25 and ibid., vol. 3, pp. clvii-clviii.

130. For the exact wording of that law see ibid., vol. 3, pp. cliii-clxvii. For its importance in the context of English master and servant law see: Simon, "Master and Servant", pp. I95-197.

I3I. Cf.: Rogers, "Regulation of Labour in Britain", pp. IO3-IO4.

132. Campbell and Skinner, Works and Correspondence of Adam Smith, p. I57.

133. Eden, The State of the Poor, vol. I, p. 295.

134. Cf. Rule, The Experience of Labour in Eighteenth-Century Industry, pp. 176-I78; Orth, "The

English Combination Acts Reconsidered”, esp. p. I3. 
Thirdly, these provisions granted the authority to penalize labourers for breach of contract (b) and other, loosely defined offences (a, b). Furthermore, the "Vagrant Act" of 1744 , the first statute of that kind relating to "the idle and disorderly", ${ }^{35}$ was also cited. This law must have appeared to Popham and other legally versed gentlemen as particularly relevant for Madras conditions as the south Indian labour force's remarkable mobility created major problems for employers and rulers. The complementarity of comparatively high wages and a remarkable level of mobility which has been mentioned before is here reflected by the attempt to use a "vagrancy" law as an instrument for the reduction of wages.

Three preconditions were thus, in Popham's view, required to regulate wages in Madras. First, the JPs and "discreet and grave persons" (of whose social position there could be not the slightest doubt) required the authority to fix pay rates. Secondly, "conspiracy", i.e. collective action on the part of labourers, had to be declared a criminal offence in order to be able to suppress it with all the Company's coercive power. Thirdly, a legal basis was necessary to punish those labourers who insisted on higher remuneration or on their mobility. These legal preconditions could be provided by "the Laws of England". Benjamin Sullivan, the cautious attorney-general in Madras, doubted the legality of Popham's proposal to introduce a municipal tax but had no objections whatsoever against the fixing of wages. ${ }^{136}$ Popham himself had admitted in another memorandum that English law per se was not in force in Madras. ${ }^{137}$ Though the legality of regulations concerning wages and labour relations was thus rather questionable, the European notables clearly considered their execution to be unproblematic.

\section{CONCLUSION}

What can be gained from the above discussion for our understanding of the early colonial regime's nature in south India? For one, the existence of a labour policy in Madras should be regarded as a gauge for measuring the early Company regime's radius of action, for measuring the extent to which the British power block in Madras was "sucked"138 into the structure of south India's economy and society as the processes of regional militarization and colonial state formation gathered speed in the latter half of the eighteenth century. The intensity of the "sociological" and legal debate about labour issues among the British notabilities in Madras as well as their

135. Rogers, "Regulation of Labour in Britain", p. I05.

I36. OIOC, MPP (P/240/63), July I3, I786, pp. II43-II44.

137. "Copy of a Letter from Mr. Popham to the Governor in Council of Madras; dated the 3Ist December 1783; on the Mode of administering Justice among the Natives of the Settlement of Madras. Ordered to be printed 5th July 1797”, OIOC, Early Parliamentary Papers Relating to India $(\mathrm{L} / \mathrm{PAR} / 2 / 32)$, p. 4 .

138. I borrow this metaphor from Bayly, Indian Society and British Empire, p. 46. 
repeated attempts to regulate wages and labour relations by means of newly built institutions testify that due to these processes the control of labour resources emerged as an urgent and distinct problem (i.e. a problem not necessarily subsumed under issues of land control). By the turn of the century the Company regime had acquired the power to intervene even in ground-level social relationships. It could no more be considered an ephemeral phenomenon without much relevance for most of Madras City's or even the wider hinterland's inhabitants. This needs to be emphasized, even though the Governor-in-Council's power was of course much greater in Madras City than in rural areas, even though there were many British misconceptions of the region's prevalent forms of social organization, even though these forms often proved inaccessible to British notabilities, keeping them thus dependent on various types of Indian intermediaries.

Our finds give also some indication as to essentially colonial features of the political order in late eighteenth-century Madras. Though the British notabilities were certainly not the only powerful force in the city's society, they were far more than just another community not interfering with the others. They sought to establish themselves as the dominating power not exclusively by way of alliance with influential indigenous groups. They also endeavoured consistently to impose institutional forms and legal techniques of domination that had been generated in England (and Scotland) upon all the city's communities, thus overriding their claims to internal selfgovernment. The incipient stages of the British elite's labour policy in Madras reveal an inherent tendency within the early colonial administration towards direct intervention in elementary aspects of social organization. What was specifically colonial about these interventions and their ideological props was not merely their origin in an alien geographical and cultural context. What was specifically colonial about late eighteenth-century labour policy in Madras was also the high degree to which means of coercion were applied to a context where the rights of a "free-born Englishman" were not to be conceded to the poor even rhetorically. The references to labour problems in the records of Fort St George do not bear out Peter Marshall's assertion that "the Company was committed to a free market in labour and to preserving the rights of its meanest subjects". ${ }^{339}$ Admittedly, the conditions of chronic labour scarcity limited the efficiency of attempts at controlling labour by compulsory means in South India as they did in Bengal. However, the application of such means was neither merely a tolerated marginal phenomenon nor was it mainly restricted to times of military crisis as Marshall believes. I have argued elsewhere that labour relations based on contract shaded into relationships based on extra-economic com-

139. Peter J. Marshall, "The Company and the Coolies: Labour in Early Calcutta", in Pradip Sinha (ed.), The Urban Experience: Calcutta; Essays in Honour of Nisith R. Ray (Calcutta, 1987), p. 31. This otherwise instructive article is a rare attempt to deal with this topic. 
pulsion even in years of peace: that the cat o' nine tails and the "rattan" complemented economic pressure when labour relations were generated or consolidated in Madras. ${ }^{\mathrm{I} 0}$ The material presented in the present article suggests, moreover, that the Madras gentlemen tended to utter the more paternalistic variety of current ideologies of social domination and hardly ever returned to the idea of the free market in respect of labour. They also tended to introduce the most interventionist regulations they could find in the British "archive" of legal techniques - regulations that had meanwhile frequently become obsolete in their country of origin. In fact, of the English institutional forms of regulating the poor, only those that relied on coercion were taken up, while those that aimed at easing social tensions through welfare measures were generally ignored. Gentlemanly labour policy in late eighteenth-century Madras differed from pre-colonial forms of controlling labour as it enforced alien institutional and legal techniques through a new type of military despotic state apparatus. It was distinguished from labour policy in contemporary England by its exceedingly coercive features. 